ORIENTE MODERNO $100(2020)$ 147-171 $\quad \begin{gathered}\text { ORIENTE } \\ \text { MODERNO }\end{gathered}$

\title{
'Our Traditions Will Kill Us!': Negotiating Marriage Celebrations in the Face of Legal Regulation of Tradition in Tajikistan
}

\author{
Elena Borisova \\ Teaching Assistant (social Anthropology), School of Social Sciences, \\ University of Manchester, Manchester, UK \\ elena.borisova@manchester.ac.uk
}

\begin{abstract}
Based on extensive ethnographic research in northern Tajikistan, this article examines the implications of the law ordering traditions and rituals (tanzim), including marriage celebrations, in Tajikistan. At the centre of my analysis is the figure of a state employed 'worker of culture', Farkhod, whose family was affected by recent, rather militant, attempts by the state to regulate tradition. By following the story of his daughter's wedding, I analyse how Farkhod tries to reconcile his roles of a caring father, a respectful community member, and a law-abiding citizen. I argue that the tanzim exacerbates the mismatch between the government's attempts to impose a rigid notion of tradition and promote the idea of a certain kind of modern citizen, and people's own understandings of being a modern and moral person having a good wedding.
\end{abstract}

\section{Keywords}

law - marriage - tradition - modernity - Tajikistan

\section{Introduction}

In December 2017, her future husband spotted Gulbahor as she was carelessly dancing at her cousin's wedding party. Since then a young man's mother started to persistently propose to Gulbahor's father, Farkhod. Although Gulbahor's parents were initially against the idea because of financial concerns, after a 
week of gathering information about the groom's family and intense family discussions, they accepted the proposal and scheduled the wedding for the upcoming spring. For Farkhod, a state employed singer in his early forties, whose main source of income and reputation stemmed from artistic performances at different life-cycle celebrations in the nearby villages and the local town, giving a daughter away (dukhtar(cha) dodan) became a matter causing never ending anxieties for the next few months. He was delighted that the proposal came from a 'cultured' (Rus. kul'turnyi) and wealthy (Taj. puldor) ${ }^{1}$ family of the former head of the neighbouring kolkhoz. At the same time, the whole process of preparation - finding creditors, renovating the house, chasing dowry items, doing paperwork - and the ceremony itself produced a lot of different concerns for Farkhod. He was terrified with the prospect of jeopardizing his reputation by being unable to afford a proper wedding for his daughter, during which he would perform willingness to do everything according to tradition for his in-laws and community (Cleuziou, 2019b), but also enact his personal imagination of what a modern person's wedding looks like. On top of that, he was concerned if he would be able to secure a proper dowry for Gulbahor to proactively please his in-laws, which in turn would signify his care and cement his reputation as a dutiful father and a proper family head (Zanca, 2011; Abashin, 2015).

The new version of the law 'On regulation of traditions, celebrations and customs in the Republic of Tajikistan' (Qonuni Jumhurii Tojikiston az 28 avgusti soli 2017, no. 1461 'Dar borai tanzimi an'ana va jashnu marosim dar Jumhurii Tojikiston' $)^{2}$ passed on August 23, 2017, aimed at eliminating some of the persistent concerns involved in organizing a wedding, such as the financial burden of hosting different events and the distribution of food and gifts for guests. In order to cut down on ritual expenses, the tanzim prescribes the form and content of the main celebrations, tightens control over compliance to the law and imposes stricter sanctions for non-compliance. These measures are believed to 'defend social interests of people of Tajikistan, to facilitate the decrease of poverty, and to prevent excessive expenditure which causes a serious damage

1 My field research was conducted in a mixture of Russian and Tajik. The region has been deeply transformed by the Soviet modernist project, and Russian is still embedded in the language landscape and entangled with Tajik in everyday speech, which is reinforced by contemporary massive migration to Russia. In this article, I give Russian or Tajik equivalents depending on how my informants used them and, where appropriate, explain the salience of using Russian instead of Tajik.

2 I refer to this law simply as the tanzim (literally regulation) in the rest of the article for the sake of readability but also because this is how my informants referred to it in everyday conversations. 
to economic interests and moral foundations of the lives of citizens' (The Law of the Republic of Tajikistan no. 1461, chapter 1, article 1:1).

Now Farkhod had to reconcile throwing a proper wedding for his daughter with new legal limitations on ritual practice, which created many mundane dilemmas during the wedding itself, e.g. who should be invited, how many dishes should be served, should gifts be distributed, etc. But apart from these new dilemmas, for Farkhod the new law has created another unexpected concern that has impacted his livelihood in the long run. Employment at the local department of culture (Rus. otdel kul'tury), a state institution responsible for providing cultural content for multiple public state celebrations brought him a salary of 82 USD a month. His part time job as a music teacher in a kindergarten gave him additional 31 USD. In summer 2016, he earned 5 ooo USD from his private performances, but after the new version of the law had been introduced, the number of invitations Farkhod received to perform at different events dramatically dropped, curtailing his income by more than half. During the winter of 2017 he was constantly confronted with the lack of money both for everyday family provision, and for Gulbahor's wedding. By the autumn 2018, when I left his family, he had not made enough money to cover his debt left after the wedding and had to consider going to Russia as a labour migrant. His experiences of balancing these different concerns were marked by intense feelings of confusion, shame, fear and lack of control. Every time he had to make an important decision concerning the wedding, Farkhod dramatically exclaimed, 'Our traditions will kill us (Rus. nashi traditsii nas ubiut)!'

Brought into stark relief by his daughter's wedding, the multiplicity of Farkhod's concerns opens up a window on the complexity of marriage arrangements in contemporary Tajikistan in the light of the state's rather militant attempts to legally regulate tradition. In line with the theme of this volume, this article looks at marriages as contested sites of (re)production of social relations, ethnic and cultural identities, and gendered subjects constituted by the broader political, legal, economic, and social contexts. Central Asian ways of getting married consist of three historically intertwined processes variously invested with value - a religious marriage (nikoh), state registration (ZAGs), and a tui - a party thrown for the community and perceived as lying in the realm of the traditional (Cleuziou, 2019a; see also Introduction to this volume). It is the tui that has become the most economically burdensome for people in the late socialist years and afterwards at the time of post-socialist economic and political upheavals (Koroteyeva and Makarova, 1998; Reeves, 2012; Ilkhamov, 2013; Rubinov, 2014; Aitieva, 2015). The marketization of ritual economy, the emergence of new consumption patterns, the decline of community support networks, the inflation of ritual expenses prompted by mass 
labour migration, and people's engagement in practices of traditionalization all contribute to making marriage an unbearably expensive endeavour (Reeves, 2012; Trevisani, 2016; Cleuziou, 2019b). Since expenditures may vary significantly in different regions and according to family's status, it is difficult to make an average estimate: Farkhod spent around 8700 USD on Gulbahor's wedding on the whole, while some of my other informants spent more than 12500 USD on their daughters' weddings. Given the official average salary of 140 USD in Tajikistan and the degree of normalisation of labour migration and the population's reliance on remittances, taking loans and seeking employment in Russia has become the main means to finance weddings. Wedding rituals have become enmeshed in migration cycles and intrinsically linked with (im)mobility, allowing people to enact their imaginations of 'the good life', but also pushing them into competition in abundance and causing more people to join the migration flow (Reeves, 2012; Ilkhamov, 2013; Rubinov, 2014). This is precisely the process the Tajikistani government claims to be trying to reverse by introducing the tanzim.

In this article, based on the 12 months of ethnographic research I conducted in 2017-2018 in rural northern Tajikistan, I focus on the implications of the new version of the tanzim on the process of marriage celebrations. I argue that, framed as an attempt to eliminate financial burden of costly rituals and, ultimately, contribute to the country's development, the tanzim creates yet another marriage quandary that adds a new level of indeterminacy to people's attempts to craft themselves as proper persons, modern subjects and good citizens. Adopting a rigid notion of tradition, the tanzim exacerbates the mismatch between the government's attempts to define the parameters of both tradition and the ideas of a modern citizen on the one hand, and people's own understandings of being a modern and moral person honouring tradition on the other. In practice, the tanzim inserts itself into the complex processes of negotiation of what should be performed during marriage conclusions. As a result, this causes confusion, complicates creating relatedness between families, and threatens people's sense of self.

\section{Studying Weddings in Central Asia}

Wedding rituals in Central Asia have long been recognised in academic literature as politically and symbolically important sites. Whereas for the Soviet modernist project they embodied inherent traditionalism, which needed to be eradicated on the path to creation of modern citizens (Poliakov, 1992), the successor states' attempts in distinguishing between bad 'wasteful' and good 
'authentic' tradition have been considered a sign of growing authoritarian tendencies. Trevisani (2016) argues that in Uzbekistan, by regulating ritual expenses, the authoritarian government penetrates intimate spaces of faith and customary practice seeking to anchor its power and get a firmer grip on the society. In Tajikistan, Roche and Hohmann (2011) argue that although the tanzim draws on the discourses of economic rationality, it reflects the state's anxieties about a 'possible loss of control over national cultural production, especially in the religious sphere' and feeds into an attempt to impose a homogeneous folklorised Tajik cultural identity as 'imagined by state authorities' (Roche and Hohmann, 2011: 125). Other scholars have mentioned the tanzim as a part of government's efforts to monopolize authority in religious and traditional spheres, e.g. through the imposition of dress codes (Ibañez-Tirado, 2016; Boboyorov, 2017) in line with the politics of 'secular extremism' (Lemon, 2016; see also Thibault, 2018).

Building upon this literature, my article focusses on how ordinary people navigate the space of ambiguity borne out of the mismatch between the state lexicon of tradition and their own understandings of social propriety of certain wedding performances informed by the ideas about culturedness, hospitality, respect, and care. My analysis is guided by two important considerations. Firstly, although the government's discourses may reflect an attempt to tighten control over the population, they are historically grounded and they do not fall on the 'bare' ground but have certain resonance with people's concerns about ever expanding ritual expenses (Koroteyeva and Makarova, 1998; Zanca, 2011; Reeves, 2012). Secondly, while Central Asian states might propagate certain homogeneous national identities, people engage in their own projects of traditionalization from the 'bottom-up' (Beyer and Finke, 2019). These projects are themselves contested and involve constant negotiations of what belongs to the realm of the traditional and needs to be performed (Cleuziou, 2019b). I analyse how the tanzim penetrates these negotiations on discursive (by making a categorical fix on the notion of tradition) and practical levels and opens up an affectively charged space of indeterminacy, which generates multiple moral and practical dilemmas.

The ethnographic data on which I base my analysis was collected within the framework of the long-term project on reverberations of normalised migration to Russia in everyday life of people in rural Tajikistan. In 2017-2018, I conducted participant observation in several villages in the Sughd region of Tajikistan, located in close proximity to the border with Uzbekistan. Living with several families who experienced labour migration, I was engaging in the minutiae of their everyday lives; a significant part of which was attending and organising life-cycle events, marriage conclusions being the most large-scale ones. In the 
centre of my analysis is the figure of Farkhod, whose spacious house became my home for almost a year. Farkhod is desperately trying to reconcile the roles of a caring father, a respected community member, and a good law-abiding citizen in the context where the resources are scarce, the ideas about tradition and modernity are contested and shifting at different levels, and the attempts to collectively figure out the 'rules' are joined by the fear of legal punishment. Farkhod is confronted with the task of simultaneously navigating and reconciling the state imaginaries of tradition with the practices of traditionalization 'on the ground'. He is left to navigate these contradictory notions when, on the one hand, as a state-employed singer, he has to play an important role in (re)producing the state's vision of modernity but by the same token, as a result of the tanzim, he has been deprived of his main source of income and struggles to make ends meet.

\section{Tanzim: The Workings of the Law}

The first version of the tanzim was passed in 2007 and, according to the president, largely benefitted ordinary citizens and resulted in the rise in the number of marriage conclusions (Roche and Hohmann, 2011; Rahmon, 2017). The new updated version of the tanzim, proposed by the president on the 11th of August 2017 and unanimously approved by the government on the 23rd of August 2017, introduced further limitations on the form and content of various celebrations. The law distinguishes between official and family celebrations. The former includes both large-scale national events accompanied by some kind of 'official spectacles' (Adams, 2010) like Independence Day (Istiqloliiat), Nation Unity Day (Vahdati Millii), Navruz (the spring equinox celebration), and formal parties thrown to celebrate appointments for state positions, promotions, state awards, and academic and professional degrees which the law bans (The Law of the Republic of Tajikistan no. 1461, chapter 3, article 7). All other celebrations - birthdays (zodruz), circumcisions (khatnasur), weddings (tuii domodiu arusii), funerals (dafnu azodorii), and pilgrimage (haj) fall under the category of family events. While some events were curtailed and allocated specific temporal and spatial frameworks, the others were simply banned by the law. Perhaps, the most widely debated move among my informants was the reduction of circumcision feast (pisar tui), ${ }^{3}$ which used to be

3 My informants used different regionally specific names, e.g. pisar tui or sunnat toi (Uzbek), never khatnasur. Some names and minutiae of rituals are influenced by the region's position on the border with Uzbekistan and mixed ethnic composition of the population. 
similar to weddings both in the scope of performance for the community and expenditure, to a small family gathering (Chylinsky, 1991; Abashin, 20o3; Ilkhamov, 2013).

As mentioned above, contemporary Tajik weddings comprise three parts, each of them validating marriage for different agents. Registration in the state registration office $(Z A G S)$ is required for a marriage to be considered legally legible by the state; the Islamic ritual (nikoh) validates marriage in a religious sense, while tui, a lavish performance of tradition, authenticates marriage for the community. The latter lasts for several weeks and consists of a sequence of smaller ritual events in which different parts of the community participate and involve constant movement and circulation of people, items, gifts, and food. Such a three-way structure has developed partly as the result of the Soviet state's attempts to reshape marriage and family life in line with its modernization project. While the civil ceremony has become mandatory, the religious one has never lost its significance (Kamp, 20o6; Roche and Hohmann, 2011; Abashin, 2015; Roche, 2016; Cleuziou, 2019a). Cleuziou (2019a) notices that contemporary Tajikistani state has inherited 'Soviet contradictions' in regulating marriages - while the Family Codex recognises only officially registered civil marriages (aqdi nikoh) as valid, it uses the word nikoh, which refers to a religious ceremony. Notably, the tanzim does not mention the religious ceremony of nikoh at all and refers to aqdi nikoh only once when stipulating the permitted number of cars in the wedding cortege (four). It focuses its interventions on the tui part, which it refers to as tuii domodiu arusii (literally, celebration of groom and bride).

Tui is far from being a unified one-time event, although people often talk about it as a totality. Transferring a bride and her dowry from her parental home into her new home, incorporating her into her new family and introducing her to domestic duties are all accompanied by a number of ritual events constituting tui. The same ritual has different local forms with some villages developing the scope of particular events into separate lavish ceremonies, entailing gatherings of many people and circulation of gifts and food (Roche and Hohmann, 2011; Abashin, 2015). ${ }^{4}$ The new version of tanzim reduced these events to small family circle gatherings (dar doirai oila) without workers of culture (be khizmatrasonii san'atkoron), slaughter of livestock (be zabhi chorvo) and inviting guests. The law also forbade ritual exchanges of gifts, usually

4 Roche and Hohmann (2011) point that after the Civil War (1992-1997), the creative potential of wedding rituals has dramatically developed and came to embody not only ethnic but also regional identities, personal ideas about modernity and connectedness with the wider world, and preferences for certain kinds of aesthetics. 
fabrics and clothes, at these events (Chapter 3 , article 10:2). ${ }^{5}$ The central event of the wedding (which the law calls ziefat - literally "banquet"), was now to be held strictly in two days (three hours per event) with maximum 150 guests allowed for the wedding itself and 200 for a preceding party. Pre-wedding parties are thrown by a bride's side for the kin, friends, and colleagues who are unable to attend the main celebration, partly due to legal limitations. They are usually held in house courtyards or in restaurants and resemble the main wedding celebration both in scope and expenditure. ${ }^{6}$

Apart from imposing new limitations on people's ritual practice, the main novelty of the new version of the law is its violent enforcement and dispersed responsibility for its implementation. ${ }^{7}$ Special tanzim committees were created to monitor people's ritual lives at the regional, town, village, and neighbourhood (mahalla) levels. Their main function is to detect lawbreakers by carrying out selective inspections like spotting an excessive number of guests at a party, noticing too many cars in the wedding cortege or observing that wedding parties last too long. Village administrations have become responsible for approving people's weddings in advance by signing permissions (ma'lumotnoma), which state the length of celebration and the number of guests allowed. The amount of prior paperwork has also increased: one needs to secure the bride and groom's medical checks' results, ${ }^{8}$ an approved application for marriage registration at the state office $(Z A G S)$, and the local administration's approval of tui to be able to conduct an Islamic religious ritual (nikoh) but also to sign a contract with a restaurant and singers. All wedding singers have been given a copy of the law requiring them to ensure the 'legality' of the event before signing a contract. Wedding halls were made responsible for controlling the number of guests and for enforcing the three-hour time

5 For the whole list of 16 banned events see The Law of the Republic of Tajikistan, 1461, chapter 3 , article 10:2. Two events, domodtalbon and arusbinon (the events I discuss in the last section of the article under their regional names domodbururon and jeghzanak) were reduced to family gatherings with up to 15 people permitted.

6 This practice varies across the regions and carries different names (Cleuziou, 2019a). In the region where I conducted my research, people referred to it as khatm-i Qur'on (recitation of Qur'an). Such gatherings are common on different occasions and it is interesting that in this case it is used as a 'compensation' for legal restrictions on the number of guests. The law has no reference to this event in religious terms but calls it dodani oshi tui - distribution of plov (traditional rice dish).

7 As Cleuziou (2019a and 2019b) noticed, the previous version of the law was not actively enforced judging by the low number of people fined.

8 Mandatory health checks before marriage were introduced in 2016 with the idea to ensure young people's capability to create a healthy family and produce offspring. Roche (2016) analysed how medicalisation of marriage is linked with the idea of a 'healthy nation'. 
limit. Religious figures, social scientists, representatives of civil society, local administrations, schoolteachers, and state workers have been allocated the task of propagating the benefits of the law among the wider public. Ordinary people learned about the new law from $\mathrm{TV}$, newspapers, and mostly local gossip. Last but not least, the law has significantly raised the fines for noncompliance: around 3250 USD for individuals, 4300 USD — for state officials (who also risk to be fired), and 5400 USD - for legal bodies. ${ }^{9}$ The first results of the tanzim's enforcement were not late in coming, and according to the head of the Tajikistani Supreme Court, 771 people were fined for almost 400,0oo USD for 'too exuberant weddings' in 2017 (Yuldashev, 2018).

\section{Moral Dimension of Expenditure: Modern Citizens and Backwards Subjects}

One sunny September day at the beginning of my fieldwork I was sitting in the teacher's room of the local school, which is always lively - teachers come and go and the breaks between lessons are filled with their gossip, laughter, and phone conversations with their husbands working in Russia. The recent version of the tanzim made a topic of that day's heated conversation. Our discussion revolved around practical issues, such as what feasts were dismissed, how many guests were allowed to a wedding, how many dishes, etc. as well as moral evaluations of state efforts to help ordinary people, embodied in the paternal figure of the president. While the majority disapprovingly shook their heads when learning about yet another limitation, one elder teacher hesitantly tried to explain the rationale of this law to me, 'You see, our country is poor, and the president wanted to help people accumulate wealth. They go to Russia, work there for years and spend it all overnight! This law is good for our people, but our people don't understand it yet - they are used to huge celebrations and it will take time to change it'.

In the coming months, I witnessed a lot of people's attempts to reason about the tanzim, reproducing and contesting the ideas about economic rationality it invokes, but also negotiating and retaining illegalized practices. There seemed to be a constant tension between praising the law as an ultimately good development for the whole society, but nevertheless circumventing it (Cleuziou, 2019b). Doing so, people would call themselves rigid, uneducated, and dumb

9 The article 481 of the Administrative Code of Tajikistan outlines the penalties. It makes a distinction between different categories of legal actors but does not distinguish between different breaches. 
subjects (Rus. nashi liudi tupye) resisting any kind of change promoted for their own good. Constant self-depreciating commentary of my informants referring to themselves as uncultured (Rus. nekul'turnyi), uncivilized (Rus. netsivilizovannyi), backwards (Rus. otstalyi), and savage (Rus. dikii) in mundane conversations about the law made me realise that it is not the pragmatic regulation of ritual expenses that made the tanzim a highly contested development. It seemed to have fed into people's already existing anxieties about tradition and modernity, which became fuelled by the mismatch between the state's lexicon of tradition and people's own understandings of what it means to be a modern person honouring tradition.

In this section, based on the analysis of the law and the official rhetoric around it, I will give the reading of the law as a modernization project, which implies the making of a certain kind of modern citizen — the one with the twofold orientation to the future and the past..$^{10}$ The orientation to the future reveals itself in embracing a certain kind of economic rationality, which prompts striving for improvement in all spheres of life for the bright future of the entire nation. This orientation to the future does not, however, break with the necessity to honour tradition, but is instead rooted in a specific understanding of tradition - a modern tradition aligned with economic needs and easily adjustable to developmental projects.

The main objectives of the tanzim are summarized in the preface of its second version, 'The present law orders traditions (an'ana), celebrations (jashn), and customs (marosim) with consideration to the demands of the development of the society and aims to defend authentic values of the national culture (arzishhoi asili farhangi millii) and respect to national customs (ehtirom ba sunnathoi mardumi) to increase the social and economic standard of living of citizens of the Republic of Tajikistan'. The law makes two intertwined sets of claims - for development and authenticity - the development is going to be achieved by cutting off ritual expenses, the excessiveness of which anyway contradicts the 'authentic' tradition. The construction and adherence to the 'right' tradition, that is, the one which does not contradict current economic needs, is considered as paving the road to a modern future.

In his speech given on the occasion of the tanzim's tenth anniversary in July 2017, the president, Emomali Rahmon, claimed the effectiveness of the law and its positive reception by the population that justified new stricter measures to be introduced. He made connections between embracing an

10 There are other projects to create a modern yet traditional in a certain way subject in Tajikistan. This project is inevitably gendered (see e.g. Ibañez-Tirado, 2016; Roche, 2016; Thibault, 2018), but the exploration of this aspect exceeds the scope of this article. 
'authentic' (asili) tradition by fighting 'immoderacy' (ziyodaravī) and promotion of the common national goals of economic and social development:

Some customs and traditions have acquired a negative character in the society because of big expenses. They caused wastefulness and did injustice to underprivileged families. [...] Lavish weddings and unreasonable expenses have not yet been eliminated in the country; some individual citizens still use customs and rituals as a means to show off and praise themselves - phenomena, which are alien to the nature of our nation and contradicting the spirit of the law. [...] The aim of this law is to raise the culture of holding celebrations, give an accurate picture of calculation of expenses and change people's attitude to adhering to such customs.

RAHMON, 2017

By fighting 'ostentatiousness' (isrofkorì) and 'immoderacy' (ziedaravī) the law is meant to teach people how to make saving money an ordinary part of their lives, so that they could redirect their resources to investment in future oriented projects. For example, article 9:5 of the law advises that parents open a bank account in their son's name to put aside money saved by cutting the circumcision feast's expenses, whereas article 10:4 suggests that money saved on food for guests during the wedding can be spent to 'improve the living conditions of the newlyweds'. In order for the society to embrace the idea of economic rationality, which would lead to poverty reduction, people need to understand 'wastefulness' of their expenses and ostentatiousness which Europe has given up in the 18th, USA - in the 19th, and Japan - in the 2oth century', as one of the MPs put it (Yuldashev, 2017). A new type of individual has to be cultivated - one who gives up the orientation to immediate benefits of raising one's status to the rational and future-oriented mentality. A popular trope of migrants wasting hard earned money 'overnight' and contributing to the 'inflation of ritual expenses', invoked by the teacher at the introductory vignette, is an illustration of the logic that needs to be eradicated. ${ }^{11}$ Those who do not comply with the new law are fashioned as backwards, immoral and unpatriotic subjects, who are not only ignorant of their own national traditions but also lack a 'humanistic attitude' to others and gratitude to the state.

11 Although the president carefully avoids the issue of labour migration in his speeches, other officials stressed the law would help the situation of labour migrants, as it is understood that the primary goal of going to Russia is to earn money for weddings (Yuldashev, 2017). My informants also understood this law as connected with the aim of reducing labour migration. 
State criticisms of conspicuous consumption and extravagant ritual expenditures are not unique to post-Soviet Tajikistan. During the Russian imperial period 'wastefulness' was criticized by Central Asian Muslim reformist authors, the Jadids, while during the Soviet period it was the state who attempted to reshape wedding rituals (Binns, 1980; Roche and Hohmann, 2011; Abashin, 2015). For the Bolsheviks the main objective was eradicating traditionalism with its 'relics of the past' to push 'backwards' Central Asian people into the socialist modernity (Poliakov, 1992). With the departure of the Soviet welfare state, new independent governments have replaced the Marxism Leninism doctrine with the ideology of national independence, which, underpinned by the hegemonic discourse on cultural authenticity, allows governments to mobilise tradition as a tactic of governance (Rasanayagam, 2011). Accounts on Tajikistan point to a similar dynamic — in its nation-building efforts, the government invokes tradition to legitimize its authority (Nourzhanov, 2001; Laruelle, 2007; Blakkisrud and Nozimova, 2010; Hughes, 2017). The tanzim articulates the 'defence of authentic values of national culture and respect to popular customs' as one of its goals. As Cleuziou (2019b: 358) points out, being a tool of some sort of 'traditionalist authoritarianism', it rhetorically and legally distinguishes between 'good' and 'bad' tradition. However, it is a very particular historically grounded notion of tradition that it utilises.

Article two of the tanzim defines tradition as a 'bunch of material and moral values of social and cultural heritage of the society or separate social groups, transmitted from one generation to another'. Such a definition resonates with the objectified and rigid Soviet-era notion of national tradition as based on the collection of 'cultural stuff' (Grant, 1995; Hirsch, 2005; Pelkmans, 2006; McBrien, 2009). Similar understanding of tradition makes it possible to delineate present tradition by listing what belongs (or rather should belong) to it and to shape it in line with current needs. ${ }^{12}$ According to the logic of the Tajikistani state, by teaching oneself to adhere to the 'right' version of tradition - the one compatible with the idea about economic rationality and the bigger goal of social and economic development of the nation - one becomes a modern individual, and a good citizen, who looks forward to the future and works hard for it to arrive, but also honours the past and tradition. This understanding of tradition, however, has little to do with affectively charged lived performances of the traditional 'on the ground'. Neither does it necessarily correspond with people's own ideas about what it means to be a modern subject and a recognized community member.

12 A similar law in Uzbekistan passed in 1998 called not only to defend local traditions from 'harmful foreign influences' but also 'create new, exemplary traditions' (Abashin, 2003). 


\section{Wedding of a Modern Person}

On the day of khatm-i Qur'on Farkhod and his wife, Zebo, were very nervous. Contradictory advice of their multiple kin as to how to do everything properly has exhausted them, and instead of anticipating the moment of glory having their hospitality, wealth and modernity recognized by the community, they were afraid something would go wrong any minute. The party took place at the local tuikhona (a wedding restaurant) - a new luxurious building standing out against the background of the huge decaying oil-extracting cotton factory. Officially they have invited 120 people but since Farkhod was a public figure, he could not really predict how many guests would turn up.

That evening both Farkhod and Zebo had to stay at the restaurant entrance to greet a never-ending flow of guests. When instead of 200 officially permitted guests, 320 people showed up and the restaurant could not provide additional seats and food for them, in addition to the fear of tanzim inspection, Farkhod felt so ashamed that he did not find a better solution than to just withdraw his persona from greeting guests. When they finally came home, Farkhod was deeply frustrated. Despite his desperate efforts to appear a good host and maintain his reputation of a wealthy but also 'cultured' man, things went not as planned. Guests did not fit in the restaurant, the men ran out of vodka, his classmates were trying to force him to drink; his colleagues played classical music instead of fast popular songs, which bored his guests; and people started to leave early.

The symbolic and existential value of conducting a proper tui in Central Asian societies cannot be exaggerated. Being a 'membership fee for the community's acknowledgement' (Ilkhamov, 2013: 280), tui marks a family's new status, structure social relations with the others, and become a basis for person's self-worth (Abashin, 2003). Part of everyday sociality in communities, these events are powerful sources of moral experience - it is through 'engaging within a project to marry and settle their children and participate fully within their community' that individuals develop an understanding of a moral self (Rasanayagam, 2011: 48). ${ }^{13}$ In this respect, weddings are also crucial sites of

13 I do not explore the aspects of morality informed by Islamic ethics for several reasons. Firstly, they did not come up ethnographically during my fieldwork, I believe, partly because of the specific past of the region profoundly transformed by the Soviet modernization project, and partly because of the omnipresent atmosphere of fear and suspicion created by the present politics of religion in Tajikistan (see e.g. Thibault, 2018). Secondly, exploring the relations between morality and Muslim selves would lead me to a different direction and demand another study. For the purposes of this article, I see my informants' understanding of being a good person (Taj. odami khub) as grounded in the collectively 
production of gendered persons. They provide people with a 'stage' on which they perform their roles of dutiful and caring fathers, husbands, sons, uncles, as well as good mothers, wives, daughters, and aunts and (re)position them vis-à-vis each other (Ibañez-Tirado, 2013). Cleuziou (2019b: 350) highlights the moral dimension of excessive spending - the ability to 'gather and redistribute wealth, food and entertainment in a short time, and to the benefit of guests' is transformed into prestige and the reputation of her informant as zani bo farhang/madaniiat - "a woman with culture". Organising his daughter's wedding, Farkhod was similarly very much concerned with his obrui qimmat, which can literally be glossed as "expensive reputation" - a reputation of a wealthy man but also a reputation demanding a lot of wealth to maintain it. Doing so, he drew on ideas coming from different idioms of tradition and modernity.

Farkhod's understanding of being 'cultured' was partly informed by his position of khizmatrasoni san'atkori (Taj. "a worker of culture"), which implied a certain social positioning in the community (Sultanova, 2005) and made him feel strong affiliation with the objectified value of culture (Adams, 2010; Klenke, 2019). Furthermore, his ideas about being a modern man were linked to experiences of socialist modernity still resonant in the region, but were likewise intertwined with post-socialist experiences, and expanding global connections (McBrien, 20o9; Mostowlansky, 2017; Stephan-Emmrich and Schröder, 2018). The local idiom of modernity is intimately connected with the Soviet modernization project, which promoted not only spectacular industrial but also social transformation turning peasants into subjects with a capacity to be a new kul'turnyi chelovek (Rus) - a "cultured man" (Volkov, 200o; Kalinovsky, 2018), an expression often used by my informants although Russian was not their first language of communication. The transformation the north of Tajikistan underwent positioned the local population in a certain way in the hierarchy of development (Mostowlansky, 2017: 77-79). It has produced 'people who believed they were modern' (McBrien, 20o9: 128) and they juxtaposed themselves with 'less modern' people from other parts of the country (e.g. the South) and the region.

Articulation of Farkhod's ambition to be 'cultured' depended on how successfully he could 'stage the traditional' but in his own way that he imagined to be appropriate for a modern man. His 'culturedness' manifested itself in his choices of the mode of celebration, place, and certain type of entertainment provided. Although the costs of hosting khatm-i Qur'on at one's courtyard

shared ideas about kinship, care, respect, hospitality, mutuality, and culturedness, which are partly expressed through the idioms of tradition or modernity. 
could be significantly lower, Farkhod insisted that they threw a party at a restaurant. He contrasted rural home weddings in dusty overcrowded backyards with aesthetically pleasing spacious wedding halls. For him, the very space of restaurant, where his guests could sit in comfort around beautifully served tables and enjoy gossiping, listening to music, dancing, and delivering praising speeches for his family would signify his ability to do things tsivilizovanno (Rus. "in a civilized way"). Farkhod claimed that if a backyard invited one to make a 'drunken mess' (Rus. bardak), in a restaurant people were likely to behave and tsivilizovanno posidet' (Rus. "to have a civilized gathering").

The practice of celebrating weddings in restaurants might challenge the traditional roles of hosts and guests (Trevisani, 2016), but it is still a host's duty to attend to guests and ensure they are pleased with food and entertainment, which usually includes providing enough alcohol and opportunity to dance. Regulating the number of guests, the tanzim was meant to help Farkhod reduce the financial costs of the event and rely on the restaurant's staff to run everything smoothly. On the one hand, the tanzim's objective to 'raise the culture of celebrations' matched Farkhod's intentions to have a 'civilized' celebration held in a restaurant. However, his willingness to comply with the law simultaneously constricted his contingent enactment of his involvement in the traditional, as he could not fully display hospitality and attend to his guests. On top of the feeling of shame before his guests, constant threat of arrival of a tanzim inspection to his overcrowded event put a lot of pressure on him. And even after this stressful wedding had been over, he could not be sure that punishment would not come upon his family because some witness could always report him.

\section{Tradition 'from below': Navigating the Changing Rules}

During pre-marital negotiations Farkhod's soon-to-be qudo ${ }^{14}$ expressed a wish to organize everything in compliance with the tanzim, stressing in the first place they wanted to do it be latta (literally "without fabrics") meaning they would not exchange gifts. Farkhod was very happy about this arrangement, as it would save him a significant amount of money and time. Three days after the wedding, they were invited to their qudo's house for the first time for domod bururon (groom's walk out) - a celebration of the groom, ${ }^{15}$ who would proudly appear with his new wife in front of guests for the first time after three days of

14 Qudo is a kinship term designating relationships of affinity.

15 Domod means both "groom" and "son-in-law". 
seclusion, having turned his wife into a woman. After the dinner, everyone was taken outside to greet the new family. Gulbahor was dressed in one of her glittering traditional dresses she received as a part of her dowry, a scarf, and a thin white piece of cloth (sari) covering her head, while her husband was wearing a traditional male gown (chapon) and a skullcap (tuppi). The couple had to demonstrate modesty as men were reciting Qur'an and guests were approaching them to greet, give a hug or a kiss and wish them a happy married life.

When we were about to leave, women started to distribute small plastic bags with gifts - scarves, handkerchiefs and fabrics. Gifts were given according to one's status - while Zebo and Farkhod received two big towels, two tablecloths, two prayer rugs, a piece of expensive fabric for a party dress, a scarf, and a shirt, his sisters and I got only one piece of fabric, a smaller towel or a tablecloth. On our way home, everyone seemed to be in an uplifted mood: Farkhod's sisters were laughing, singing his songs and gossiping about their new relatives who appeared to be a wealthy and respectful family. When our conversation turned to gifts, his elder sister explained laughing, 'I've been at their place today and they gave me something, so I also must give them something the next time, I am indebted. We try to get rid of our debts as soon as possible so we will invite them to different events. When I open my sanduk (a big wooden chest usually decorated with national ornaments every woman brings to her new home as a part of dowry), I immediately remember who gave me those things, so I know whom to invite'.

Although everyone was cheerfully chatting, Farkhod looked grumpy and remained silent. They came home very tired but instead of taking rest, Farkhod and Zebo had a heated family discussion about the event they would host the next day.Jeghzanak (from Taj.jegh zadan — to invite, and zanak — woman) is a bride's first visit to her home in a new status, which the tanzim has reduced to a family circle celebration with no more than 15 people allowed. Nevertheless, Farkhod's family would still try to outperform the groom's family in hospitality by serving more dishes and better decorating the table even for a smaller number of guests. Making a list of items to be purchased, Farkhod felt frustrated and anxious because his in-laws distributed gifts despite their agreement to stick to the law. As a result, now he would also have to give them almost identical but slightly more expensive or more aesthetically pleasing gifts the other day, although it exceeded his budget. On top of that, they decided to prepare more food than needed for the 15 people expected to come the next day, because since their in-laws already broke their promise once, they did not know how many people would show up. Not reciprocating gifts and being unable to accommodate, feed and entertain everyone who turns up at their 
doorstep would bring shame (aib) to their family in the eyes of their qudo and raise Farkhod's anxieties about his daughter's treatment in her new family. Later, in our discussion about the tanzim, Farkhod explained people's inability to fully comply with it by constant mistrust present in marriage negotiations regarding many aspects, including the bride's dowry, 'If they [the in-laws] are decent people, they will say they don't need anything, you can buy furniture and other things later, they just want your daughter. But no one trusts such words. Everyone lies! [...] After the wedding she [mother-in-law] will say, "oh, we thought your father was rich but he didn't give you anything! He doesn't care about you!'”

My ethnography shows that the tanzim, which has forbidden all kinds of gift exchanges during marriage celebrations, has not necessarily meant that people stopped these practices. People generally agreed that the government's intervention was a good development and tried to interpret and appropriate the law in ways that would benefit them and reduce financial burden of weddings. Some of these attempts were more successful than others - for example, cutting the number of hours of wedding banquets was less contested than cutting the number of guests. At the same time, instead of eradicating burdensome gift exchanges the introduction of the tanzim has only further complicated already quite messy process of negotiation of mutual expectations and rules. As a result, families have to engage in new negotiations exposing them to unexpected dilemmas with missing tools to solve them, which adds another level of uncertainty to the business of marriage conclusions.

My interpretation of the complexity of marriage quandaries is guided by two significant points which do not correspond with the logic of the tanzim. Firstly, being the central ritual of passage in the lives of young people and gaining even more significance due to labour migration (Roche, 2014: 173-174), marriage celebrations are one of the main sites of articulation of people's identities and ideas about the good life, which are inextricably connected with tradition. However, tradition needs to be understood both as contested and subject to negotiation, and flexible, always incorporating new elements. Recognizing tradition as 'affectively powerful' and in line with Beyer and Finke's (2019: 312) call to pay attention to how tradition 'is done', i.e. how it is 'enforced, enacted, and lived', my ethnography pushes to think about people's understandings and enactment of ideas about proper wedding celebrations vis-à-vis the ideas promoted by the tanzim. The second aspect the tanzim seems to forego is the importance of marriage conclusions for sustaining and creating relatedness and one's social standing in the community. A properly organized wedding is the first step in creating a harmonious relationship 
between two families. Effort put into it is interpreted as a sign of care for one's children, which is a moral obligation of every adult man (see Zanca, 2011: 110; Abashin, 2015: 588). Attention to the intersection and interaction of different logics - the logic of the law and the logics of the 'ground level' tradition sheds light on why the state's intervention is welcomed but cannot be followed in a straightforward way.

The mismatch between the state and popular understandings of the traditional in marriage celebrations is reflected in different vocabularies used to address both different parts of marriage conclusions, as I showed earlier, and tradition itself. Although the tanzim refers to tradition with the Tajik words an'ana, jashn va marosim, which can be literally translated as "tradition, feast and ceremony", ${ }^{16}$ no one used them in everyday conversations. While explaining the meaning of certain ritual performances to me, my informants used a number of Russian words - traditsiia (tradition), obychai (custom) and zakon (law). Complaining about the burdensome nature of these performances they usually disapprovingly shook their heads or produced an embarrassed smile or laugh (often both at the same time) and said, 'U nas obychai/zakon takoi' (Rus. "this is our custom/law"). Sometimes they said, u nas tak (Rus) or injo hamin hel ast (Taj), which is a statement of a hard fact — 'it's like this here'. Yet, explaining the meaning of some ritual actions and gift exchanges to each other, Farkhod and Zebo always referred to the Tajik word qoida, which can be translated as a "custom" or a "rule", e.g. the same word is used to designate grammatical rules or rules of etiquette. Like Kyrgyz salt, which is discussed as "customary law" in literature, reference to qoida 'obviates the need for further explanation because it carries the force of law' (Reeves, 2012; Beyer, 2016).

Although qoida is imagined as a static historically continuous entity, there is a lot of room for fluidity, flexibility and change. In rapidly changing societies more variation can be expected in terms of interpretations and acceptance of different practices traveling in and out of tradition (Beyer and Finke, 2019). Tajik marriage conclusions have experienced a rapid change since the beginning of the 2oth century and in the past decades have incorporated further practices resembling the patterns of modernizing weddings in other contexts, such as increased reflexivity and participation of the young generation in marital choices, growing variation in modes of celebration, commercialization of wedding ceremonies, and the use of conspicuous consumption to mark social status (e.g. Kendall, 1996; Yalçin-Heckmann, 20o1; Trevisani, 2016). White bridal dress and professional make-up, wedding cortege with decorated cars, photo

16 On the complexity and translatability of the lexicon of tradition in Central Asia see Beyer and Finke (2019). 
shoots, dancing to music, serving beautifully decorated salads and nibbles, drinking alcohol, video recording, distributing invitation cards for the guests in advance are all important attributes of contemporary Tajik weddings. ${ }^{17}$ The tension between the representation of qoida as unchanging and unquestionable and its practical open-endedness, as well as the ability to incorporate new elements means that following qoida is less about knowing details of a particular ritual but 'working it out together' as Cleuziou discusses in her study of dowry as a traditionalization practice (Cleuziou, 2019b: 349). She also notices that new elements get incorporated in tradition not according to a temporal dimension but a spatial one - it is not what one's ancestors used to do in the past but what one's neighbours are doing in the present that becomes a rule to follow. The process of figuring out and negotiating what needs to be done is emotionally draining, it is fraught with ambiguity and bears potential consequences for people's social standing and relations.

Creating and sustaining relatedness is one of the things that marriage does (Carsten, 2000). A properly orchestrated wedding ceremony apart from rising one's status and sustaining one's reputation in the community, is the first step to building harmonious relationship between two families and maintaining relationships with one's own kin who is always involved in the process at different stages. During wedding performances families engage in the staging of relations of reciprocity and mutual help but also competition through gift exchanges and elaborate displays of hospitality (Cleuziou, 2019b). Affine relations are marked by authority and power (Cleuziou, 2019a) and are highly ritualised: they firstly get established by marriage and then maintained through years of 'going and coming' and 'giving and receiving' (Beyer, 2016: 142). Gift exchanges that create mutual indebtedness are interpreted as a sign of paying respect and considered to be a contribution to strengthening ties. However, it is not only the idiom of 'amity' (Beyer, 2016) that informs relationships between in-laws.

Aib budet! (It will be shame!) - the way Farkhod explained to me in a mixture of Tajik and Russian the reason why he engaged in situations and behaviours which caused him more effort and expense he would like to incur. The Tajik word aib can be translated as 'shame' - the emotion which in the Kyrgyz context (uiat), Beyer glossed 'shame-anxiety'.18 She defines it as an

17 For some detailed descriptions from across Central Asia see McBrien (2006), IbañezTirado (2013), Trevisani (2016), Cleuziou (2019a, 2019b). For the transformations of wedding rituals in the 2oth century see Abashin (2015: 547-611).

18 For a detailed discussion on shame-anxiety (aib in the Tajik, uiat in the Kyrgyz context), see Harris (2005: 69-91), Beyer (2016: 147-152), Cleuziou (2019b: 354-355). 
'emotional practice by means of which individuals are socialised into subjecting themselves to an awareness of other's expectations' (Beyer, 2016: 148). Farkhod was very well aware of the need to meet his qudo's expectations for the sake of his daughter's well-being. However, the tanzim made it difficult to know what exactly those expectations were and thus to be able to effectively negotiate them. He read his qudo's promise to organise everything in compliance with the law as a genuine sign of respect for his family, originating from the shared understanding of his financial hardship related to 'giving a daughter', which notoriously exceeds the costs of marrying off a son. In some way, the rhetoric of compliance with the tanzim would both portray him as a good citizen and help him 'trick' tradition which demanded excessive spending. However, for his qudo's the rhetoric of reducing costs was a convenient excuse to lure Farkhod into the match he was hesitant to agree to. Gulbahor was only 19, in her second year of university studies, and Farkhod was not ready financially for her wedding. But when his soon-to-be in-laws reassured him many times that there would not be many expenses, and his kin did their research on the groom's family reputation and confirmed they were wealthy, kul'turnye and khondagi (Taj. 'educated'), Farkhod gave in. However, his new relatives were wealthier, more well-connected, and eagerly demonstrated their networks during the wedding, so they could afford (or at least acted so) not to really care about possible sanctions. Once agreed for the match, haunted by the prospect of shame and anxieties for Gulbahor's future treatment in her new family, Farkhod was forced to act according to the (fluctuating) rules of reciprocity and keep up with the competition initiated by his in-laws.

\section{Conclusion}

In this article, I have looked at the Tajikistani state's attempts to reshape celebrations of marriage conclusions in line with the goals of economic development. In particular, I have looked at the reverberations of the last version of the law on ordering traditions, rituals and ceremonies (tanzim) for people's attempts to enact their understandings of proper marriage celebrations, which is intimately linked with the ideas about the self and community. The state (Soviet and then Tajikistani) has long attempted to control marriage practices by framing it in certain ways. Imposing a rigid notion of tradition, compatible with the ideas about economic rationality, the tanzim aims to reshape wedding celebrations in order to cut off burdensome expenses and help people accumulate wealth. The new version of the tanzim gives strikingly specific and detailed instructions on what counts as a proper marriage celebration, 
although it discusses only one part of it - tui - which is associated with conspicuous consumption. It is also marked with a militant stance on enforcement of these instructions backed up by new bureaucratic infrastructure and serious sanctions for law-breakers.

The introduction of the law has raised people's concerns about social disruption. While people generally agreed with the government's rhetoric, which portrayed 'ostentatious' weddings as a sign of backwardness and moral degradation, some illegalized practices persisted and people complained that rather than helping to save money, the tanzim caused them more trouble. Some critical reports appeared in the media: e.g. the article titled 'Tanzim and Real Life' argues that the tanzim ruins young families since 'modest' weddings have become the reason for 'disparagement of honour and decency' of newly-wedded couples (Asia-Plus, 2017). The juxtaposition of the legal and social realities such title invokes hints that there is a mismatch between the perception of marriage celebrations as a state framed matter and people's onthe-ground struggles to organize a proper tui, which combines new and old practices variously framed as modern or traditional by different actors. While the government is concerned with the economic side of expenditure, people are more concerned with its moral dimension that directly affects their dignity and reputation in the community. The law frames excessive spending on extravagant weddings as immoral and forces people into choices that prevent them from having proper marriage celebrations. The result is that compliance with the law is consequential for the ways in which people locate themselves in the community. It threatens their sense of self, jeopardising their reputations of caring parents, generous and hospitable community members, and throwing their social relations into question. In other words, the state makes the articulation of people's ideas of good marriage conclusion nearly impossible.

My ethnography also shows that although the government attempts to make an intervention in the business of marriage conclusions in a unidirectional and ruthless manner, the state and ordinary people do not just talk past each other. The tanzim opens up a space of indeterminacy, within which people are trying to contest, negotiate and appropriate the law in ways that would benefit them - cut down on wedding expenses and portray them as good citizens. Borne out of the mismatch between the government's lexicon of tradition and its lived performances during weddings, this space becomes affectively charged as the tanzim inserts itself in complex negotiations of what makes a proper wedding celebration within new constrains. At the same time, people are trying to figure out how constricting new limitations are in practice. As people are probing the boundaries of the legally possible, marital negotiations become inflicted with mistrust - one never knows if explicit claims match 
one's true intentions, like Farkhod's in-laws breaking their agreement of no gifts showed.

\section{Acknowledgements}

I am very grateful to my dear colleagues and friends, Madeleine Reeves, Ekaterina Zheltova, Sara Pozzi, Nada Abdulla, Eduard Claudiu Vasile, and Mercy Oke-Chinda, who patiently discussed my ideas with me, commented on different versions of this article and helped sharpen my argument. I also thank warmly the editors of this volume, Julie McBrien and Juliette Cleuziou for their comments and suggestions, and their enthusiasm and support, and the anonymous reviewers who helped me improve the article at final stages. All mistakes and inaccuracies are, of course, mine.

\section{References}

Abashin, S. (2003). "Vopreki zdravomu smyslu"? (K voprosu o 'ratsional'nosti / irratsional'nosti ritualnykh raskhodov v Srednei Azii)”. In: Evraziia: ludi i mify. Moscow, Natalis, p. 217-238.

Abashin, S. (2015). Sovetskii kishlak: mezhdu kolonializmom i modernizatsiei [A Soviet village: between colonialism and modernity]. Moscow, Novoe literaturnoe obozrenie.

Adams, L. (2010). The Spectacular State Culture and National Identity in Uzbekistan. Durham-London, Duke University Press.

Aitieva, M. (2015). Reconstituting transnational families: an ethnography of family practices between Kyrgyzstan and Russia. Unpublished PhD thesis. Manchester, University of Manchester.

ASIA-PLuS (2017) 'Tanzim' i realnaia zhizn' [Tanzim and real life]. Available at: https://asiaplustj.info/news/tajikistan/society/20171123/tanzim-i-realnaya-zhizn (Accessed: 15 December 2019).

Beyer, J. (2016). The Force of Custom: Law and the Ordering of Everyday Life in Kyrgyzstan. Pittsburgh, University of Pittsburgh Press.

Beyer, J.; Finke, P. (2019). "Practices of traditionalization in Central Asia', Central Asian Survey, 38, 3, p. 310-328. doi: 10.108o/o2634937.2019.1636766.

Binns, C.A.P.(1980) "The Changing Face of Power:Revolution and Accommodation in the Development of the Soviet Ceremonial System: Part II", Man. Royal Anthropological Institute of Great Britain and Ireland, 15, 1, p. 170-187. doi: 10.2307/2802008.

Blakkisrud, H.; Nozimova, S. (2010). "History writing and nation building in postindependence Tajikistan". Nationalities Papers, 38, 2, p. 173-189. doi: 10.1080/o ogo5990903517835. 
Boboyorov, H. (2017). "Tajikistan: Between security and objectification of female body". New Eastern Europe, November. Available at: https://neweasterneurope.eu/ 2017/11/13/tajikistan-security-objectification-female-body/ (Accessed:10June 2020).

Carsten, J. (ed.) (2000). Cultures of relatedness: new approaches to the Study of Kinship. Cambridge, Cambridge University Press.

Chylinsky, E. (1991). "Ritualism of Family Life in Soviet Central Asia: The Sunnat (Circumcision)". In: Akiner, S. (ed.). Cultural Change and Continuity in Central Asia. London, Kegan Paul, p. 16o-170.

Cleuziou, J. (2019a). "Marriage Practices: Tajikistan”. In: Joseph, S. (ed.). Encyclopedia of Women \& Islamic Cultures Marriage Practices. http://dx.doi.org/10.1163/1872-5309 _ewic_COM_oo2195.

Cleuziou, J. (2019b). “Traditionalization, or the making of a reputation: women, weddings and expenditure in Tajikistan". Central Asian Survey, 38, 3, p. 346-362. doi: 10.1080/02634937.2019.1617247.

Grant, B. (1995). In the Soviet House of Culture: A Century of Perestroikas. Princeton, Princeton University Press.

Harris, C. (2005). Control and Subversion: Gender Relations in Tajikistan. London, Pluto Press.

Hirsch, F. (2005). Empire of nations: ethnographic knowledge \& the making of the Soviet Union. Ithaca, Cornell University Press.

Hughes, K. (2017). "From the Achaemenids to Somoni: national identity and iconicity in the landscape of Dushanbe's capitol complex". Central Asian Survey, 36, 4, p. 511533. doi: 10.108o/o2634937.2017.1319796.

Ibañez-Tirado, D. (2013). Temporality and subjectivity in Kulob, Southern Tajikistan: an ethnography of ordinary people and their everyday lives. Unpublished PhD thesis. London, SOAS University of London.

Ibañez-Tirado, D. (2016). “Gold Teeth, Indian Dresses, Chinese Lycra and 'Russian' Hair: Embodied Diplomacy and the Assemblages of Dress in Tajikistan". The Cambridge Journal of Anthropology, 34, 2, p. 23-41. doi: 10.3167/ca.2016.340203.

Ilkhamov, A. (2013). "Labour migration and the ritual economy of the Uzbek extended family". Zeitschrift für Ethnologie, 138, 2, p. 259-284.

Kalinovsky, A.M. (2018). Laboratory of socialist development: Cold War politics and decolonization in Soviet Tajikistan. Ithaca, Cornell University Press.

Kamp, M. (2006). The new woman in Uzbekistan: Islam, modernity, and unveiling under communism. Seattle, University of Washington Press.

Kendall, L. (1996). Getting married in Korea: of gender, morality, and modernity. Berkeley, University of California Press.

Klenke, K. (2019). The sound state of Uzbekistan popular music and politics in the Karimov era. Abingdon, Routledge. 
Koroteyeva, V.; Makarova, E. (1998). "Money and social connections in the Soviet and post-Soviet Uzbek city". Central Asian Survey, 17, 4, p. 579-596. doi: 10.108o/ o2634939808401057.

Laruelle, M. (2007). "The return of the Aryan myth: Tajikistan in search of a secularized national ideology". Nationalities Papers, 35, 1, p. 51-70. doi: 10.1080/oog05990601124462.

Lemon, E.J. (2016). "Building resilient secular citizens: Tajikistan's response to the Islamic State". Caucasus Survey, 4, 3, p. 261-281. doi: 10.108o/23761199.2016.1219028.

McBrien, J. (2006). "Listening to the wedding speaker: Discussing religion and culture in Southern Kyrgyzstan". Central Asian Survey, 25, 3, p. 341-357. doi: 10.1080/o2634930601022591.

McBrien, J. (2009). "Mukadas's Struggle: Veils and Modernity in Kyrgyzstan”. Journal of the Royal Anthropological Institute, 15, p. 127-144. doi:10.1002/9781444324402.ch8.

Mostowlansky, T. (2017). Azan on the moon: entangling modernity along Tajikistan's Pamir Highway. Pittsburgh, University of Pittsburgh Press.

Nourzhanov, K. (2001). "The Politics of History in Tajikistan: Reinventing the Samanids". Harvard Asia Quarterly, 5, 1, p. 21-30. doi: 10.1484/m.srs-eb.4.00274.

Pelkmans, M. (2006). Defending the border: identity, religion, and modernity in the Republic of Georgia. Ithaca, Cornell University Press.

Poliakov, S.P.; Brill Olcott, M. (1992). Everyday Islam: religion and tradition in rural Central Asia. Armonk-NewYork, M.E. Sharpe.

Qonuni Jumhurii Tojikiston az 28 avgusti soli 2017, no. 1461 'Dar borai tanzimi an'ana va jashnu marosim dar Jumhurii Tojikiston' [The Law of the Republic of Tajikistan from 28th August 2017 no. 1461 on regulation of traditions, celebrations and customs in the Republic of Tajikistan].

Rahmon, E. (2017). “Rech' na vstreche po sluchaiu 1o-letiia Zakona Respubliki Tadzikistan 'Ob uporiadochenii traditsyi, torzhestv i obriadov $\mathrm{v}$ Respublike Tadzikistan" [Speech on the meeting dedicated to the tenth anniversary of the law ordering traditions, celebrations and rituals in the Republic of Tajikistan]. Available at: http://prezident.tj/ru/node/15752.

Rasanayagam, J. (2011). Islam in post-Soviet Uzbekistan the morality of experience. Cambridge; Cambridge University Press.

Reeves, M. (2012). "Black Work, Green Money: Remittances, Ritual, and Domestic Economies in Southern Kyrgyzstan". Slavic Review, 71, 1, p. 108-134. doi: 10.5612/ slavicreview.71.1.0108.

Roche, S. (2014). Domesticating youth:youth bulges and its socio-political implications in Tajikistan. New York, Berghahn.

Roche, S. (2016). "A sound family for a healthy nation: motherhood in Tajik national politics and society". Nationalities Papers, 44, 2, p. 207-224. doi: 10.108o/ oogo5992.2015.1087486. 
Roche, S.; Hohmann, S. (2011). "Wedding rituals and the struggle over national identities". Central Asian Survey, 3o, 1, p. 113-128. doi: 10.108o/o2634937.2011.554065.

Rubinov, I. (2014). "Migrant Assemblages: Building Postsocialist Households with Kyrgyz Remittances". Anthropological Quarterly, 87, 1, p. 183-215. doi: 10.1353/ anq.2014.00o6.

Stephan-Emmrich, M.; Schröder, P. (eds.) (2018). Mobilities, Boundaries, and Travelling Ideas: Rethinking Translocality Beyond Central Asia and the Caucasus. Cambridge, UK: Open Book Publishers. doi: 10.11647/OBP.o114.

Sultanova, R. (2005). “Music and Identity in Central Asia:Introduction”. Ethnomusicology Forum, 14, 2, p. 131-142. doi: 10.1080/17411910500329989.

Thibault, H. (2018). Transforming Tajikistan: state-building and Islam in Post-Soviet Central Asia, Transforming Tajikistan. London; New York, I.B.Tauris.

Trevisani, T. (2016). "Modern weddings in Uzbekistan: Ritual change from above and from below". Central Asian Survey, 35, 1, p. 61-75. doi:10.108o/o2634937.2015.1114781.

Volkov, V. (2000). "The concept of kul'turnost': notes on the Stalinist civilizing process". In: Fitzpatrick, S. (ed.). Stalinism: New Directions. London-New York, Routledge, p. 210-231.

Yalçin-Heckmann, L. (2001). The Political Economy of an Azeri Wedding. Max Planck Institute for Social Anthropology.

Yuldashev, A. (2017). "Parlament Tadzhikistana prinial popravki k zakonu ob uporiadochenii traditsyi. Pridanim nevest zaimutsia pozzhe" [The parliament of Tajikistan amended the law on ordering traditions. Brides' dowry will be taken care of later]. Available at: https://asiaplustj.info/ru/news/tajikistan/power/20170823/par lament-tadzhikistana-prinyal-popravki-v-zakon-ob-uporyadochenii-traditsii -pridanim-nevest-zaimutsya-pozzhe.

Yuldashev, A. (2018) 'Za 'cherezchur pishniye svad'bi' Tadzhikov oshtrafovali pochti na \$500 ooo" [Tajiks were fined for almost \$500 ooo for "too ostentatious weddings'], The Open Asia. Available at: https://theopenasia.net/ru/post/za -chereschur-pyshnye-svadby-tadzhikov-oshtrafovali-pochti-na-50o-ooo.

Zanca, R.G. (2011). Life in a Muslim Uzbek village: cotton farming after Communism. Belmont, California, Wadsworth, Cengage Learning. 